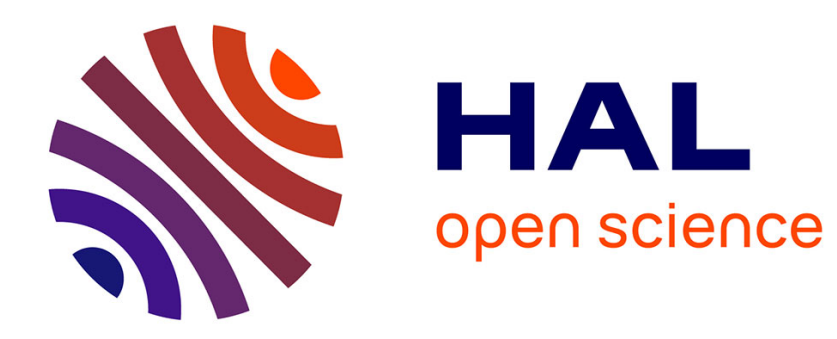

\title{
Climate change: Back to development
}

\author{
Michel Damian, Luigi de Paoli
}

\section{To cite this version:}

Michel Damian, Luigi de Paoli. Climate change: Back to development. Economics and Policy of Energy and the Environment, 2018, LIX (2017) (3), pp.5 - 24. 10.3280/EFE2017-003001 . hal01870974

\section{HAL Id: hal-01870974 https://hal.science/hal-01870974}

Submitted on 5 Nov 2018

HAL is a multi-disciplinary open access archive for the deposit and dissemination of scientific research documents, whether they are published or not. The documents may come from teaching and research institutions in France or abroad, or from public or private research centers.
L'archive ouverte pluridisciplinaire HAL, est destinée au dépôt et à la diffusion de documents scientifiques de niveau recherche, publiés ou non, émanant des établissements d'enseignement et de recherche français ou étrangers, des laboratoires publics ou privés. 


\title{
Energy and environmental observatory
}

\section{Climate change: Back to development}

\author{
Michel Damian* and Luigi De Paoli**
}

\begin{abstract}
The Paris Agreement has created a double bifurcation. First, from top-down approach (with an emissions limit imposed from above) to a bottom-up approach based on national emissions reduction pledges. And second, from a mitigation-centered policy to a more balanced mitigation and adaptation efforts. The following work proposes, however, that further steps must be taken to bring the theme of development back to the center of the fight against climate change.

The article is divided into four parts. First is a reflection on the fact that mitigation has captured much of the attention during the past twenty years, but that adaptation is progressively gaining importance in policies to combat climate change. The next section explains why, starting from the Framework Convention on Climate Change in 1992, the objective of the "stabilization of greenhouse gases concentrations in the atmosphere at a level that would prevent dangerous anthropogenic interference with the climate system" has led first to define the increase of $2^{\circ} \mathrm{C}$ as the limit not to be exceeded, then to the search for an equivalent level of $\mathrm{CO} 2$ concentration and last to the related carbon budget. The third part shows why the goal of not exceeding the $2{ }^{\circ} \mathrm{C}$ temperature increase is illusory when considering the discrepancy between actual mitigation policies and theoretical commitments required based on the data presented by the IPCC. Even salvation coming from negative emission technologies at the moment seems more theoretical than real. The final conclusions state that, given the insufficiency of the mitigation tools, adaptation must be taken seriously - not as a passive solution, but as a conception of a different kind of development, which is required not only to fight climate change, but also for other purposes.
\end{abstract}

Keywords: climate change, adaptation, mitigation, sustainable development, Paris agreement.

JEL classification: Q54, F53, Q01

First submission: 13 February 2018, accepted: 7 July 2018

\section{Acknowledgements}

The Authors would like to thank Christian de Perthuis for reading and the stimulating comments of the draft of this article.

* Professeur Émérite à l'Université Grenoble Alpes, Laboratoire GAEL, Axe Energie. E-mail: michel.damian@univ-grenoble-alpes.fr.

* Department of Social and Political Sciences, Bocconi University, via Roentgen 1, 20136 Milan, Italy. E-mail: www.luigi.depaoli@unibocconi.it. 


\section{Adaptation: the progress of the poor relative in the climate negotia- tions}

The Paris Agreement, developed at the $21^{\text {st }}$ Conference of Parties (COP21), led to a bifurcation from a "top-down" approach, like that of the Kyoto Protocol, to a "bottom-up" approach based on emission reduction pledges and national policies the so-called "Intended Nationally Determined Contributions" (INDCs) (Damian, 2014, 2016). However, there is another major turning point that is much less commented on, namely, the centrality of policies for adaptation to climate change (Lesnikowski et al., 2017).

For the first time since the beginning of climate negotiations a little more than a quarter of a century ago, adaptation to global warming has become a priority that is difficult to disentangle from the question of development.

The climate regime, "for the past 15 years or more has focused on intellectual, political, diplomatic and fiscal resources on mitigation while downplaying adaptation" (Pielke Jr. et al., 2007, 598). There was an initial bias against adaptation (Damian, 2007), which was considered to be a politically incorrect solution (Burton, 1994). "Believing that we can adapt to just about anything is a kind of laziness, an arrogant faith in our ability to react in time to save our skin". These are the words of Vice President Al Gore from 1992 (quoted in Pielke Jr., 1998, 162). In that bygone time, there was a belief in the possibility of quickly reducing emissions.

For economists, focused on emissions reduction and market incentives, such as carbon trading, there was no scope for adaptation. Addressing adaptation and its cost and effectiveness is more complex, as Michael Hanemann writes: "These are empirical questions. They are not questions that can be answered simply by recourse to economic theory. The answers are likely to vary by location and by time, as well as by type of impact and by actor. The answers are contingent and context-dependent. Adaptation is local. There cannot be a single answer that applies globally. [...] Governments are likely to have a key role here: by themselves markets may not be adequate" (Hanemann, 2008, slides 5 and 35). More than 40 years ago, Thomas Schelling was one of the first, and rare economists, to insist on the need to anticipate climate change and, thus, to adapt to it $(1983,481)$; this position has been greatly criticized.

The belief in the capability of mitigation to avoid climate change has, for a long time, been almost unbreakable. This initial confidence has led to the consideration of adaptation but also to the use of development policies as strategies that can only undermine efforts to organize global emission reduction (Rousset, 2012). Assuming that emission reduction and adaptation can be a matter of development, the transformation of production structures and social needs has been removed from sight, from the vocabulary and from the analysis of the majority of economists and experts in developed countries who are exclusively concerned with the reduction of emissions. However, times are changing.

In the INDCs proposed by the States for the Paris Conference, the term "adaptation" is mentioned 2,780 times, against 1,956 mentions of "mitigation" (Dovie and Lwasa, 2017). Adaptation is ubiquitous in the 53 INDCs of the African countries. 
Agriculture, renewable energies and water appear to be high priorities: these concerns are present, respectively, in 52, 48 and 46 of the 53 INDCs of the African continent (Mékouar, 2017). For example, Morocco, host of the COP22 held in Marrakech in November 2016, devoted $64 \%$ of its climate expenditure to adaptation between 2005 and 2010, which was equivalent to $9 \%$ of its overall investment expenditure. This share could exceed 15\% in 2030 (Morocco, 2015).

It took many years for adaptation to find a place in the negotiations: there was almost no consideration of adaptation prior to the 2000s (DeLeo, 2017) and it was not mentioned at the COP1 meeting held in Berlin in 1995. The term was used 18 times at the COP5 in Bonn in 1999, 75 times at the COP6 in The Hague in 2000 and 203 times at COP10 in Buenos Aires in 2004.

The rise of the occurrence of the notion of adaptation is even more significant in the different agreements signed over the last 25 years. The term "adaptation" appears four or five times in the United Nations Framework Convention on Climate Change (UNFCCC) (1992), three times in the Kyoto Protocol (1997), 11 times in the Copenhagen Accord (2009) and 77 times in the Paris Agreement (2015).

\section{Mitigation and the limit to stay within non-dangerous anthropogenic interference}

Understanding why the debate on climate change has, for a long time, been dominated by discussions of mitigation, i.e., reductions of greenhouse gases (GHGs) emissions, is quite straightforward but it is also easy to understand why adaptation is now progressively growing in importance.

Everything stems from the United Nations Framework Convention on Climate Change whose "ultimate objective" was the "stabilization of greenhouse gas concentrations in the atmosphere at a level that would prevent dangerous anthropogenic interference with the climate system. Such a level should be achieved within a timeframe sufficient to allow ecosystems to adapt naturally to climate change, to ensure that food production is not threatened and to enable economic development to proceed in a sustainable manner" (UNFCCC, 1992, Art. 2).

The goal of the Convention appears to be clear: emissions must be reduced to stabilize the concentration of GHGs in the atmosphere. In fact, the goal was not so precise. What is dangerous interference? What is the GHGs concentration level that does not threaten food production or economic development? This vagueness should not be surprising; it is probably inevitable when it comes to reaching multilateral political agreements and transcribing them into a text acceptable to all the parties involved. Unfortunately, the vagueness conflicts with the need for an operational definition, i.e., transformed into something that informs what must be done and how the results can be verified.

From a political point of view, what matters are the consequences of climate change but the cause-effect chain is long and goes from emissions through to atmospheric concentrations, radiative forcing, temperature increases and climate change, to finally arrive at the physical and socio-economic impacts (IPCC, 2013, 710). The 
relevance of the various effects increases downwards but, at the same time, the uncertainty also increases and our scientific knowledge does not allow us to say with great accuracy which emissions correspond to a particular level of impact.

In the fight against climate change, the definition of what constitutes a "dangerous anthropogenic interference with the climate system" has, therefore, remained the Gordian knot to be disentangled. The first step towards the definition of a measurable "dangerous" quantitative limit that should not be breached was made by orienting the discussion on global warming, measured by the increase in the "global average temperature above pre-industrial levels". This became the more or less conscious focal point of the negotiations. The political consensus on the value of a $2{ }^{\circ} \mathrm{C}$ increase as the limit beyond which the world would enter into the zone of possible danger has widened with time and, for the first time in the COP negotiations, the Copenhagen Accord (UN, 2009) indicated this value as a threshold that should not be exceeded:

1. "[...] To achieve the ultimate objective of the Convention to stabilize greenhouse gas concentration in the atmosphere at a level that would prevent dangerous anthropogenic interference with the climate system, we shall, recognizing the scientific view that the increase in global temperature should be below 2 degrees Celsius, on the basis of equity and in the context of sustainable development, enhance our long-term cooperative action to combat climate change. ...

2. We agree that deep cuts in global emissions are required according to science, and as documented by the IPCC Fourth Assessment Report with a view to reduce global emissions so as to hold the increase in global temperature below 2 degrees Celsius, and take action to meet this objective consistent with science and on the basis of equity".

Since then, this limit has been progressively accepted in all climate negotiations and is one of the pillars of the Paris Agreement. Consequently, this can be considered as the new formulation of "the ultimate objective" of the fight against climate change (Gao, Gao and Zhang, 2017). In this regard, it has to be underlined that the $2^{\circ} \mathrm{C}$ limit is a political decision ${ }^{2}$, not a scientific conclusion, even if reference has been made to the scientific basis for choosing it.

The two degrees limit as a catalyst for the fight against anthropogenic climate change has been widely discussed. It has been strongly criticized by some for being inherently inadequate (e.g., Victor and Kennel, 2014) or too high (e.g., Hansen et al., 2013), while others have supported it. For our part, we share the opinion that the limit

\footnotetext{
${ }^{1}$ Note that no official text defines how to calculate the "global average temperature" or what the "pre-industrial levels" (plural in the Paris Agreement) of the temperature actually are. Since everyone ignores this problem of lack of clarity, we will use the term "temperature increase" as if it had a unique and well-defined measure.

${ }^{2}$ There can be no doubt about this statement. The Intergovernmental Panel on Climate Change (IPCC), itself, clearly affirms that: "Determining what constitutes 'dangerous anthropogenic interference with the climate system' in relation to Article 2 of the UNFCCC involves value judgements. Science can support informed decisions on this issue, including by providing criteria for judging which vulnerabilities might be labelled "key'" (IPCC, 2007, AR4 SYR). This is even truer when moving from "key vulnerabilities" to a single measure that represents them.
} 
of the two degrees is neither "a threshold separating a domain of safety from a domain of catastrophe" nor "a strategy to optimize the relation between the costs and benefits of limiting greenhouse gas emissions" but it is "a solution to a complex coordination problem" (Jäger and Jäger, 2010, 3). Agreement on the goal of two degrees is a helpful act against climate change as it provides something against which commitments and results can be measured. It is obvious, however, that this objective lies downstream in the cause-effect chain and to be operational, it is necessary to start from the radiative forcing (RF) that is supposedly consistent with the temperature increase of $2^{\circ} \mathrm{C}$ and to consider the concentrations and emissions that cause it.

For some years, and especially since the fourth IPCC Report, the goal of not exceeding the two-degree increase of the equilibrium global average temperature seemed to be equivalent to the goal of stabilizing the concentration of GHGs in the atmosphere at $450 \mathrm{ppm}$ of $\mathrm{CO}_{2}$-eq (IPCC, 2007, SYR). This alternative formulation, consistent with the UNFCCC text that speaks of the "stabilization of GHG concentrations", quickly generated a series of " $450 \mathrm{ppm}$ scenarios". For example, in its World Energy Outlook (WEO) of 2008 the International Energy Agency (IEA) considered two climate-policy scenarios: "A 550 Policy Scenario, in which the concentration of greenhouse gases is stabilised at 550 parts per million of $\mathrm{CO}_{2}$ equivalent, resulting in a temperature rise of around $3^{\circ} \mathrm{C}$ and a 450 Policy Scenario, in which the concentration is stabilised at $450 \mathrm{ppm} \mathrm{CO}_{2}$-eq with a temperature rise of around $2^{\circ} \mathrm{C}^{\prime}$ (IEA, WEO, 2008, 407). The IEA confirmed the choice to assume the $450 \mathrm{ppm}$ scenario as a reference for the policies to combat climate change in all the subsequent WEOs until 2016. In its WEO-2017, for the first time, the IEA introduced a scenario entitled the "Sustainable Development Scenario", which was supposed to be in line with the United Nations Sustainable Development Agenda for 2030 (IEA, 2017, 38). Although referring to a single international body, this recent change of name (or objective?) is not accidental and can be explained in different ways. First, as we noted in the previous section, we are increasingly moving in the direction of considering the fight against climate change as one of the constituent elements of the pursuit of sustainable development. Second, the $450 \mathrm{ppm}$ level of $\mathrm{CO}_{2}$-eq has already been attained and it makes no sense to pretend to ignore this fact. ${ }^{3}$ Finally, moving from two degrees to $450 \mathrm{ppm}$ does not lead to progress on the road to setting an operational objective: both are measurable quantities but it is emissions that matter.

In fact, the fifth assessment report of the IPCC (AR5), while reaffirming that "Scenarios reaching atmospheric concentration levels of about $450 \mathrm{ppm} \mathrm{CO}_{2}$-eq by 2100 are consistent with a likely chance to keep temperature change below $2^{\circ} \mathrm{C}$ relative to pre-industrial levels" (IPCC, 2014, AR5-WG3-SPM, 12), developed scenarios of climate change (especially of temperature increase) in a different way. First, in terms of RF at 2100, different targets were selected (2.6, 4.5, 6.0 and $8.5 \mathrm{~W} \mathrm{m-2)}$ and then GHGs and aerosol emissions that were consistent with those targets and

\footnotetext{
${ }^{3}$ According to European Environmental Agency (EEA)calculations, the total concentration of all GHGs, including cooling aerosols, reached a value of $445 \mathrm{ppm}$ in $\mathrm{CO}_{2}$ equivalents in 2015 (EEA, 2018, 5). If we add the increase of $\mathrm{CO}_{2}$ concentration in 2016 and 2017 (respectively, 2.84 and $2.19 \mathrm{ppm}$ (ESRL-NOAA, 2018), we reach the threshold of $450 \mathrm{ppm}$.
} 
with their corresponding socioeconomic drivers were developed simultaneously. A corresponding level of GHG concentration was also calculated. The end result was that those scenarios were consistent with an interval of temperature increase associated with a certain probabilistic assessment.

The new methodology of constructing scenarios with a RF target, called Representative Concentration Pathways (RCP), has been associated with a new calculation method of the total emissions consistent with the goal of keeping warming below a certain global mean surface temperature (GMST) increase. According to AR5, "The ratio of GMST change to total cumulative anthropogenic $\mathrm{CO} 2$ emissions is relatively constant over time and independent of the scenario. This near-linear relationship between total $\mathrm{CO} 2$ emissions and global temperature change makes it possible to define a new quantity, the transient climate response to cumulative carbon emission (TCRE), as the transient GMST change for a given amount of cumulated anthropogenic $\mathrm{CO} 2$ emissions, usually $1000 \mathrm{PgC}^{4}{ }^{4}(\ldots)$ Expert judgment based on the available evidence suggests that TCRE is likely between $0.8^{\circ} \mathrm{C}$ and $2.5^{\circ} \mathrm{C}$ per $1000 \mathrm{PgC}$, for cumulative emissions less than about $2000 \mathrm{PgC}$ until the time at which temperature peaks" (AR5, WG1 Technical Summary, 102-3).

This is an important innovation because it shifts the focus from concentrations to emissions, in particular, carbon. Indeed, to have a given probability of not exceeding a temperature increase of two degrees, the total amount of GHGs emissions that can be released over a certain period is certainly a much more operational element when it comes to defining the allowable emission trend. In particular, the AR5 scenarios indicate the total GHGs emissions and the corresponding cumulative carbon emissions in order to remain below a given temperature increase. Non- $\mathrm{CO}_{2}$ forcing constituents are lower but are certainly important. Unfortunately, to date, few studies have considered non- $\mathrm{CO}_{2}$ forcings. ${ }^{5}$ Therefore, since carbon emissions are the most important and the most known, to stay below the two degrees of temperature increase, attention has been focused on the value of carbon emissions estimated at 990 (range 510-1505) $\mathrm{GtCO}_{2}$. One can, therefore, speak of a "carbon budget", which is probabilistically associated with a certain temperature increase. ${ }^{6}$

The carbon budget has attracted much attention but, so far, has not succeeded in becoming the focal point for decisions taken in international negotiations. This is for at least two reasons. First, although the IPCC' value is usually taken as a reference, there are large margins of scientific uncertainty about the emissions budget that is compatible with not exceeding two degrees of temperature increase. Second, if the global level of permissible emissions was to be agreed, international negotiations would have to decide how this would be divided between the different countries. In this way, we would be in danger of approaching the deadlock that led to the failure

\footnotetext{
${ }^{4}$ According to IPCC-AR5: "Equilibrium climate sensitivity undoubtedly remains a key quantity, useful to relate a change in GHGs or other forcings to a global temperature change" but "The TCR and the transient climate response to cumulative carbon emissions (TCRE) are often more directly relevant to evaluate short term changes and emission reductions needed for stabilization" (IPCC, AR5-WGI, Ch. 12, 1107).

${ }^{5}$ This is another significant weak point in our current knowledge.

${ }^{6}$ For calculations and the significance of the carbon budget, see also CTI (2018).
} 
of the negotiations for the post-Kyoto Protocol, which was only exceeded by the INDCs that do not provide a predefined level of global emissions.

\section{Where we are today and the future prospects for mitigation}

In 25 years of negotiations on climate change, we have moved on from the principle that States should "prevent dangerous anthropogenic interference with the climate system" to the acceptance of the goal of "holding the increase in the global average temperature to well below $2^{\circ} \mathrm{C}$ " (Paris Agreement, Art. 2, par. 1a). At the same time, to be consistent with the temperature increase limit, we have moved from a GHGs concentration ceiling to a "carbon budget", even if no value has, so far, been recognized in an international commitment ${ }^{7}$. The problem of using only mitigation to tackle climate change arises precisely from the low probability of reconciling the current, most accepted, carbon budget with the limit set for the temperature increase.

The most accepted carbon budget is the AR5 estimate of the RCP2.6 scenario, which is consistent with the limit of $2^{\circ} \mathrm{C}$ (see Tab. 1).

To update this data, we must take into account emissions in the 2012-2017 period. The current annual emissions of $\mathrm{CO}_{2}$ (which are the best-known data) are about $33 \mathrm{Gt}$ from the combustion of fossil fuels (IEA, 2017), $36 \mathrm{Gt}$ if we include cement production and other industrial processes (UNEP, 2017) and about $40 \mathrm{Gt}$ including emissions from all anthropogenic sources (TCI, 2018). Based on official data ${ }^{8}$, we can estimate that over the last six years, carbon emissions have been at least 200 $\mathrm{GtCO}_{2}$. Accordingly, the remaining carbon budget in 2018 is about 800,900 and $1,200 \mathrm{GtCO}_{2}$ depending on the desired probability (above $66 \%, 50 \%, 33 \%$, respectively) of staying below $2^{\circ} \mathrm{C}$ of temperature increase.

\footnotetext{
${ }^{7}$ Although we believe that setting a commitment on the total amount of carbon to be emitted would be a step forward in the fight against climate change, this does not mean that we consider the "carbon budget" a completely adequate and sufficient target. First, we should also count the impact of other greenhouse gases. Secondly, the carbon budget as proposed does not consider the evolution of carbon emissions and absorption by non-fossil sources. Certainly the contribution of the other sources or sinks (land use, forests, oceans and soils) to the evolution of the amount of carbon in the atmosphere is much more difficult to estimate, but it can not be neglected. Focusing on fossil carbon emissions is therefore just another way to simplify the problem of fighting against climate change.

${ }^{8}$ According to the IEA, world $\mathrm{CO}_{2}$ emissions from fuel combustion were $128.3 \mathrm{Gt}$ between 2012 and 2015 (IEA, 2017a). Adding the emissions from fuel combustion in 2016 and 2017 and emissions from other sources, we reach a value of at least $200 \mathrm{Gt}^{\mathrm{CO}_{2}}$.
} 
Tab. 1 -Cumulative emissions compatible with limiting warming to below $2^{\circ} \mathrm{C}$ according to IPCC-AR5

\begin{tabular}{|c|c|c|c|c|c|c|}
\hline \multirow{3}{*}{$\begin{array}{l}\text { Limit of cumulative } \\
\text { emissions from the } \\
\text { beginning of industrial } \\
\text { era: }\end{array}$} & \multicolumn{6}{|c|}{ Probability of remaining within $2^{\circ} \mathrm{C}$ of temperature rise } \\
\hline & \multicolumn{2}{|c|}{$>33 \%$} & \multicolumn{2}{|c|}{$>50 \%$} & \multicolumn{2}{|c|}{$>66 \%$} \\
\hline & $\mathrm{GtC}$ & $\mathrm{GtCO}_{2}$ & $\mathrm{GtC}$ & $\mathrm{GtCO}_{2}$ & $\mathrm{GtC}$ & $\mathrm{GtCO}_{2}$ \\
\hline $\begin{array}{l}- \text { All anthropogenic } \\
\text { emissions }\left(\mathrm{CO}_{2} \text { and }\right. \\
\left.\text { non- } \mathrm{CO}_{2}\right)\end{array}$ & 1570 & 5760 & 1210 & 4440 & 1000 & 3670 \\
\hline$-\mathrm{CO}_{2}$ only & 900 & 3300 & 820 & 3010 & 790 & 2900 \\
\hline $\begin{array}{l}\mathrm{CO}_{2} \text { already emitted by } \\
2011\end{array}$ & $515 \pm 70$ & $1890 \pm 260$ & $515 \pm 70$ & $1890 \pm 260$ & $515 \pm 70$ & $1890 \pm 260$ \\
\hline $\begin{array}{l}\text { Remaining } \mathrm{CO}_{2} \text { to be } \\
\text { emitted from } 2012 \\
\text { onwards }\end{array}$ & 380 & 1410 & 300 & 1120 & 270 & 990 \\
\hline
\end{tabular}

Source: IPCC, WG1AR5, SPM, 27

Let us look at the rate at which we are consuming this budget. To obtain a lower limit of emissions estimate, let us consider only the energy sector and ignore other carbon emissions. According to the IEA New Policies Scenario, carbon emissions

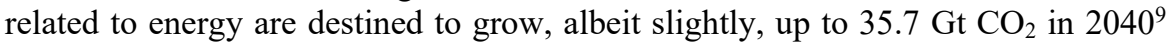
(WEO, 2017, 650). In total, the energy sector will emit around $800 \mathrm{GtCO}_{2}$ between 2018 and 2040, thus, completely exhausting the AR5 available carbon budget with $>66 \%$ probability. This date moves forward by only three to four years even accepting a $50 \%$ probability of respecting the temperature increase limit of $2{ }^{\circ} \mathrm{C}$. Since

\footnotetext{
${ }^{9}$ Note that, "The New Policies Scenario is the central scenario of World Energy Outlook, and aims to provide a sense of where today's policy ambitions seem likely to take the energy sector. It incorporates not just the policies and measures that governments around the world have already put in place, but also the likely effects of announced policies, as expressed in official targets or plans. The Nationally Determined Contributions (NDCs) made for the Paris Agreement provide important guidance as to these policy intentions in many countries, although in some cases these are now supplemented or superseded by more recent announcements - including the decision by the US administration to withdraw from the Agreement" (WEO, 2017, 37). If there had been no effort to reduce the emissions and the past trend had continued unaltered, the results would have been far worse. For example, the EEA adopts $480 \mathrm{ppm} \mathrm{CO}$-eq as a limit for not exceeding $2{ }^{\circ} \mathrm{C}$ with a $66 \%$ probability and calculates, "assuming that 2006-2015 trend of annual increases in the total greenhouse gas concentration (i.e. $3.5 \mathrm{ppm}$ per year) will continue in the coming years, this $480 \mathrm{ppm}$ threshold could be exceeded in the next 10 years" or "in about 16 years" if we consider a concentration level of $500 \mathrm{ppm} \mathrm{CO}$-eq, corresponding to a $50 \%$ likelihood of keeping the increase of temperature below $2^{\circ} \mathrm{C}$ (EEA, 2018).
} 
switching from $35 \mathrm{Gt}$ to zero $\mathrm{CO}_{2}$ emissions from $2041-45$ onwards is unthinkable, it is clear that - according to the IEA based-scenario - there is a very low chance of respecting the $2{ }^{\circ} \mathrm{C}$ degree limit.

A further reason for pessimism comes from looking at how many of the fossil fuel reserves known today should actually be left underground in order to avoid exceeding the available carbon budget. Many studies have calculated that the carbon content of fossil fuel reserves is much higher than the quantity that can be emitted to stay below $2^{\circ} \mathrm{C}$ (e.g., Heede and Oreskes, 2016; McGlade and Ekins, 2014); not to mention that, in addition to reserves, there are also resources that are much more abundant than reserves. ${ }^{10}$ For example, the latest energy study from the BGR calculates that the theoretical $\mathrm{CO}_{2}$ emissions of burning conventional reserves of fossil fuels are about 3,000 $\mathrm{GtCO}_{2}(2,045 \mathrm{Gt}$ embodied in the hard coal and lignite, 524 in the crude oil and 404 in natural gas) and 49,800 $\mathrm{GtCO}_{2}$ if we consider all fossil resources (BGR, 2017, 41). These data show that even if only considering current reserves, three- quarters of them (with different percentages ${ }^{11}$ ) should be left underground to limit emissions to below the allowable carbon budget. However, it is in the interests of energy companies and also the governments of the producing countries to extract most of these reserves. Only a very strong political intervention, which is not currently on the horizon, could significantly change the course of events.

If current trends and economic interests push in the direction of being unable to meet the objective of not exceeding $2^{\circ} \mathrm{C}$ of temperature increase, how can we consider remaining below this threshold? Focusing again on only $\mathrm{CO}_{2}$ emissions (without at all excluding the fact that attention should also be paid to other GHG sources), there are three possibilities (separately or in combination) that provide hope for success: (1) the carbon budget is much greater than estimated, (2) the pathway of emissions is deeply modified and (3) the technologies of carbon dioxide removal (CDR) from the atmosphere are successfully developed and quickly implemented.

Aiming for the first possibility is like gambling. For example, if we accept that there is a $33 \%$ probability of winning the bet of two degrees, the current carbon budget would have to increase by $50 \%$ (from 800 to $1,200 \mathrm{GtCO}_{2}$ ) and there are certainly more chances of achieving this limit. Similarly, since the equilibrium climate sensitivity (ECS), i.e., the temperature increase if the $\mathrm{CO}_{2}$ concentration in the atmosphere doubles, is uncertain, it may be that its value is lower than usually assumed. For example, AR5 states that the ECS value is "in the range $1.5^{\circ} \mathrm{C}$ to $4.5^{\circ} \mathrm{C}$ with high confidence, extremely unlikely less than $1^{\circ} \mathrm{C}$ (high confidence) and very unlikely greater than $6^{\circ} \mathrm{C}$ (medium confidence)" (IPCC, 2014, WG1 AR5, TS, 81).

10 "Reserves are generally taken to be those quantities that geological and engineering information indicates with reasonable certainty can be recovered in the future from known reservoirs under existing economic and operating conditions" (BP, 2017). New discoveries or technical progress can transform resources into reserves.

${ }^{11}$ According to the last Emission Gap Report, "between 80 and 90 percent of coal reserves worldwide will need to remain in the ground, if climate targets are to be reached. This compares with approximately 35 percent for oil reserves and 50 percent for gas reserves" (UNEP, 2017, XV). 
We could adopt the lower level of this range and, consequently, increase the amount of $\mathrm{CO}_{2}$ that could be emitted without exceeding two degrees. However, as Shelling wrote, it does not "make economic sense, or any other kind" to focus on the "extreme tail of the distribution" $(2007,4)$ (even if new estimates become available, these must be taken into consideration ${ }^{12}$ ).

The second possibility is like stating a tautology. The possibilities of reducing carbon emissions do exist. Therefore, as long as the carbon budget is not exhausted, one can always think of drastically reducing emissions to stay within its limit. However, the longer the $\mathrm{CO}_{2}$ emission rate remains at the current level (or even grows), the greater and faster (and more difficult) it will be to reduce emissions in the future: "Delaying additional mitigation to 2030 will substantially increase the challenges associated with limiting warming over the 21 st century to below $2^{\circ} \mathrm{C}$ relative to preindustrial levels. It will require substantially higher rates of emissions reductions from 2030 to 2050; a much more rapid scale-up of low-carbon energy over this period; a larger reliance on CDR in the long term; and higher transitional and longterm economic impacts" (IPCC, 2014 ar5/syr/SYR_AR5_FINAL, 24). The principle that given the difficulty in immediately reversing the route it is first necessary to slow down the growth of emissions and then to reduce them drastically, has been accepted from the beginning. Finally, this was reiterated in the Paris Agreement: "In order to achieve the long term temperature goal set out in Article 2, Parties aim to reach global peaking of greenhouse gas emissions as soon as possible, recognizing that peaking will take longer for developing country Parties, and to undertake rapid reductions thereafter in accordance with best available science, so as to achieve a balance between anthropogenic emissions by sources and removals by sinks of greenhouse gases in the second half of this century..." (Art. 4.1). Yet, observing what has happened and what is happening, how likely is it that there will be a drastic acceleration in the political commitment to reach the required level of mitigation? This is the question that must be answered honestly. For the time being, not only are the promises made with the NDCs (Nationally Determined Contributions) of the Paris Agreement insufficient but also the policies that have actually been implemented do not fully comply with these commitments (UNEP, 2017, xvii). This is an officially recognized fact. For example, a recent OECD-ITF report states: "NDCs provide $\mathrm{CO} 2$ reduction ambitions, but not yet clear pathways or measures to reach ambitions set by the Paris agreement. Often, measures in the NDCs are desired outcomes and remain vague at the best. In some cases, the mitigation potential of identified 'measures' is contestable" (OECD-ITF, 2018, 5). This is not the result of the bad will of governments: if it were so easy and cheap to change the economic paradigm and focus on a decarbonized economy, why not make decisions in this direction? Of course, there would be winners and losers but governments could indemnify losers or set them aside if the winners were more numerous and well organized. If this does not happen, one must assume that the least-cost solutions to decarbonize

${ }^{12}$ A recently published study tends to narrow the ECS range to $.2 .2-3.4^{\circ} \mathrm{C}$ (Cox, et al., 2018). The central value of this estimate $\left(2.8^{\circ} \mathrm{C}\right)$ is somewhat lower than that adopted by the $\mathrm{IPCC}$ in $\mathrm{AR} 5\left(3^{\circ} \mathrm{C}\right)$. 
the economy are more expensive and more difficult to implement than the global emission reduction scenarios implicitly suppose. For example, the replacement of coal with gas (without impeding the development of renewable sources) in electricity production is generally accepted as one of the least expensive and fastest ways to reduce carbon emissions (De Paoli, 2015). Can we then imagine that countries like China or India will quickly give up the use of coal, which is an internal resource and employs millions of people? The latest UNEP Emissions Gap Report indicates that coal not only continues to dominate electricity production, with 1,964 GW installed, but that there are $273 \mathrm{GW}$ under construction and $570 \mathrm{GW}$ in various stages of development (UNEP, 2017, 38-39). Existing plants and those under construction can be considered as committed emissions if governments do not find ways to turn them into stranded assets for investors (with or without compensation). This example is just an illustration of the fact that there are solutions to reduce emissions in a relevant way and, theoretically, at low cost, but in respect of these decarbonization policies, they are not around the corner.

The third possibility relies on the sterilization of emission overshooting through the development and implementation of technologies that are able to remove the excess $\mathrm{CO}_{2}$ emitted above the carbon budget. In fact, all current scenarios that seek to draw a pathway that limits the temperature increase to less than $2{ }^{\circ} \mathrm{C}$ provide a large contribution of negative emission technologies (NETs) but this is neither simple nor certain: "Depending on the level of overshoot, overshoot scenarios typically rely on the availability and widespread deployment of bioenergy with carbon dioxide capture and storage (BECCS) and afforestation in the second half of the century. The availability and scale of these and other CDR technologies and methods are uncertain and CDR technologies are, to varying degrees, associated with challenges and risks" (IPCC, 2014, 23, AR5, SPM). The doubts about the possibility of a strong contribution coming from the CDR are numerous. One such doubt emerges from the costs that would be needed to extract the required amount of $\mathrm{CO}_{2}$. According to Vidal (2018), "to remove just $1 \%$ of global emissions would cost around $\$ 400 \mathrm{bn}$ a year, and would need to be continued for ever. Storing the CO2 permanently would cost extra". Other doubts concern the environmental impact: "Ultimately, achieving large carbon removal rates and volumes would require very large tracts of land and potentially huge volumes of water" (UNEP, 2018, 60). Finally: "While bioenergy and carbon capture and storage are relatively mature technologies individually, there is very little deployment of them in combination, especially at a large scale" (UNEP, 2018, xxiii). A few years ago, for example, carbon capture and storage (CCS) was seen as a promising technology (IPCC, 2005) but very little progress has so far been made to lower its costs and increase its use. This example shows that it would be highly imprudent to think that because some technological solutions already exist, mitigation efforts can be limited to the assumption that technology will solve every problem. We can safely rely even less on Direct Air Capture with Carbon Storage (DACCS), which is at a "piloting stage, so it is hard to judge its technical and economic potential". We can, therefore, accept the following conclusion of the recent report of the Science Advisory Council of the European Academies: "Having reviewed the scientific evidence on several possible options for $\mathrm{CO} 2$ removal using 
negative emission technologies, we conclude that these technologies offer only limited realistic potential to remove carbon from the atmosphere and not at the scale envisaged in some climate scenarios (as much as several gigatonnes) of carbon each year post-2050" (EASAC, 2018, 1) ${ }^{13}$.

The examination of current trends and possibilities for avoiding overshooting or reabsorbing allow us to predict that, on the basis of official figures, it is more likely than not that the increase in temperature compared to the pre-industrial period will be higher than two degrees by the end of the century. This is a belief shared by many experts that supports the maximum effort to limit GHGs emissions.

In spite of this, to date, the official line is that the ceiling of $2^{\circ} \mathrm{C}$ will not be exceeded and that it may even still be possible to stay below $1.5^{\circ} \mathrm{C}$. This position is probably due to the desire not to call into question the Paris Agreement that expects "holding the increase in the global average temperature to well below $2^{\circ} \mathrm{C}$ above pre-industrial levels and pursuing efforts to limit the temperature increase to $1.5^{\circ} \mathrm{C}$ above pre-industrial levels". As such, signatory Parties have asked the IPCC to "provide a special report in 2018 on the impacts of global warming of $1.5^{\circ} \mathrm{C}$ " (UNFCC, 2015). This document is expected to be issued in October this year but a draft - some 1,000 pages - was completed in September 2017 and is currently under review by experts. However, a copy has been leaked (Reuters, 2018). From the rumours, it seems that, among other things, the document will openly say that:

- the possibility of limiting warming to $1.5^{\circ} \mathrm{C}$ by the end of this century is "extremely unlikely" (Hood, 2018);

- the only possibility to have a chance of limiting global warming to this level is by rapidly removing $\mathrm{CO}_{2}$ from the atmosphere, i.e., by pursuing "negative emissions" (afforestation and reforestation, land management to increase carbon in soil, carbon capture and storage [CCS], bioenergy with CCS, enhanced weathering, ocean fertilization, direct air capture [DAC] and storage) ${ }^{14}$.

If this is confirmed, the importance of these statements will not be so much in terms of their content (quite obvious according to the analysis carried out) but in marking the beginning of a change in the official line in the fight against climate change.

While waiting for this IPCC study to be published, other research centres that have set themselves the goal of seeing if and how it might be possible to meet the $1.5^{\circ} \mathrm{C}$ limit. Recently, Nature published a study signed by Rogelj and 22 other scholars that presents "a set of stringent climate change mitigation scenarios consistent with an increase of $1.5^{\circ} \mathrm{C}$ in $2100^{\prime \prime}$. The conclusion of the paper is that many scenarios exist that can achieve a radiative forcing of $1.9 \mathrm{~W} / \mathrm{m} 2$ (consistent with an increase of $1.5^{\circ} \mathrm{C}$ ). An easy criticism, which the authors themselves are aware of, is that what is "feasible dynamics in a model might be infeasible in the real world". Another limit

\footnotetext{
${ }^{13}$ For a broader analysis of the economy and the challenges of geoengineering and negative emissions technologies, cf. Faran and Olsson, 2018 and Honegger and Rainer, 2018.

${ }^{14}$ This point has been confirmed by Jonathan Lynn, spokesman of the UNFCCC (Reuters, 2018).
} 
of these exercises is that: "Real-world feasibility of a particular scenario also depends on factors that are not covered by current integrated assessment models (such as social support) or enabling factors (such as rapid technological developments)" (Rogelj et al., 2018). These crucial factors are the time required for socio-economic transformations to move to low or no-GHGs emission systems ${ }^{15}$ and the development and diffusion of technologies such as the CDR and, particularly, the BECCS.

We can, therefore, say that exercises with a $1.5^{\circ} \mathrm{C}$ target have the sole utility of showing the increase in the difficulty of satisfying the conditions to meet this limit compared to the $2^{\circ} \mathrm{C}$ target. The hopes that these conditions will be respected are obviously still lower than those of the two degrees.

\section{Mitigation and adaptation: the two legs of sustainable development}

What we have said so far can be summarized in three steps.

First, the $2^{\circ} \mathrm{C}$ increase has now become the landmark that is considered to be the limit beyond which one enters into the area of "dangerous anthropogenic interference with the climate system". This simplifying assumption does not correspond to an on-off risk situation and is open to criticism since the environmental stress measures are numerous (and, perhaps, some are more representative). However, it is not useful to strive to change it. What matters is that the $2^{\circ} \mathrm{C}$ has become the recognized and universally understandable element that indicates the need to make significant efforts to combat climate change.

Second, in the meantime, climate change, as well as the increase in temperature, are underway and it is very likely that the $2^{\circ} \mathrm{C}$ increase will be exceeded, although it is difficult to officially acknowledge this. To affirm this does not mean that man is not responsible for climate changes nor that he cannot and should not strive to limit them as much as possible. ${ }^{16}$ Not having the courage to say it for fear of destroying a symbol or of lowering arms in the fight against climate change risks provoking a worse effect later. If and when it becomes clear that the two degrees will be breached, it will be more difficult but, nevertheless, necessary to explain that, in any case, it is convenient to continue to struggle to reduce the human impact on climate change as much as possible. Hence, it would be good to say openly today that even if the two degrees were breached, it makes sense to exert the maximum possible effort to limit emissions.

Third, talking about concentration levels of GHGs in the atmosphere and the carbon budget is more operational. Although setting a ceiling on cumulative carbon

${ }^{15}$ One of the most frequent criticisms of the models is that they show that the cost of moving to become a low GHGs company is limited because they assume that the least-cost solutions are realized worldwide. Yet it is not at all certain that the order of implementation of the solutions goes from the least expensive to the most expensive at the national level and, even more so, at the international level.

${ }^{16}$ Economic theory suggests that the optimum situation is achieved when marginal costs equal marginal damages. However, the common hypothesis is that it is very difficult to reach and go beyond this level. Hence, the justification of the shared opinion that the fight against climate change should be pushed as far as possible. 
emissions does not guarantee to reach carbon neutrality, i.e "to achieve a balance between anthropogenic emissions by sources and removals by sinks of greenhouse gases in the second half of this century, on the basis of equity, and in the context of sustainable development and efforts to eradicate poverty" (Paris Agreement, art. 4.1), this could be an important step forward. But so far the ceiling of the carbon budget has not been set and it does not seem likely that an international agreement can be reached in the near future. The greater the current carbon emissions, the less remains for the next decades and for future generations. The principle of progressively strengthening emission reductions has been accepted since the Framework Convention. However, most studies conclude that by the middle of the century (or before) the available carbon budget that will limit the increase in temperature by two degrees will be exhausted. To solve the problem of the highly probable "overshooting", all models show that it will be necessary to develop negative emissions technologies (NETs). However, even the NETs are viewed with a little suspicion by the defenders of mitigation because they could be an excuse to continue with undisturbed emissions pending a technological solution that may never arrive. Thus, it would be highly imprudent to think that because some technological solutions already exist every problem will be solved. It would be equally wrong to think of not supporting research to gain better knowledge and to further the development of CDR. Knowing that the carbon budget is limited and that, even in the long term, it will be difficult to replace fossil fuels in some uses, some form of carbon removal will be necessary.

The conclusion of this analysis is that there is no way that the efforts to limit emissions and to develop NETs should be slowed down but the current and foreseeable efforts do not seem to be able to halt climate change. Hence, we need to ask ourselves: what else can we do? The answer is that we must (perhaps more consciously) consider the fight against climate change in a holistic way, that is, as part of a pathway that guides the development of socio-economic systems.

In a proactive approach that takes account of the impact that the development of human activities has on the climate and the impact that climate change has on human activity, there are two possible actions: mitigation and adaptation. Sometimes the same action can be called mitigation or adaptation. To take the example of wind energy, clearly, its development can be conceived as a mitigation action because it avoids the use of fossil fuels in power generation. However, a recent study shows that climate change increases windiness and, therefore, leads to a greater development of wind production as adaptation to new conditions (Scott Hosking et al., 2018). More generally, the development of renewable sources can be seen as a policy of mitigation or adaptation and the same can be said for some agricultural production.

Adaptation does not damage mitigation; rather, it is part of the same response strategy. Instead, the thesis that we need to focus only on mitigation risks being counterproductive because it launches the message that a final solution to the problem of global warming is possible without resorting to adaptation. If, as is likely, the flaunted goal of the $2{ }^{\circ} \mathrm{C}$ was not respected, the damage would be even more serious if in the meantime the adaptation was not pursued. Moreover, the comparison between mitigation and adaptation policy shows that the latter has many advantages 
over the former. Adaptation brings benefits, even in the short term, for those who promote it, while the benefits of mitigation go to everyone, even those who do not pay (like future generations). This is one of the reasons why adaptation policies are easier to undertake. They do not require complicated negotiations and international agreements. In addition, financial aid to developing countries in the context of the fight against climate change, strongly supported by the Paris Agreement, is easier to implement with mitigation policies linked to local development conditions.

Despite this, as we noted at the beginning of this paper, the attention of those who deal with climate change has focused (and continues to be predominantly oriented) on mitigation. However, things are changing and adaptation is gaining in attention and importance, although it is not yet completely clear what adaptation, its role and its governance mean. Nina Hall, for example, noted the "epistemic ambiguity" of the concept (2017) and the poor identification of support activities for adaptation on an international scale; suggesting that "there are more attempts to govern adaptation than many mitigation-focused accounts of the international climate regime would suggest" (Hall and Persson, 2017).

Trying not to emit GHGs (= mitigation) suggests something negative. Although adaptation, too, can be thought of as a passive response it can also be viewed positively as a different development model that takes emissions into account. Therefore, adaptation has two sides: the first is a response to climate change (it is hotter, so the use of air-conditioning systems is spreading); the second is an intentional way to drive development, taking account of climate change (new forms of agriculture, realization of new buildings according to the zero-energy criterion, conceiving urban mobility differently from the past, etc.). This second meaning is gradually becoming dominant

A timid example of the change of perspective is evidenced by Nicholas Stern. In his famous review, he considered adaptation "crucial to deal with unavoidable impacts of climate change to which the world is already committed" but with "limits to what adaptation can achieve" (Stern, 2007, 457). However, a short time later, he wrote, "adaptation is essentially development in a more hostile climate" (Stern, 2009, 68). Hall's awareness of the change of perspective is much more explicit: "Adaptation shifted from a technical response to a specific impact of climate change, to a much broader term which overlapped with development" (Hall, 2017, 44). Others have suggested that there must be an "adaptive development, a form of development that mitigates risks without negatively influencing the well-being of human subjects and ecosystems" (Agrawal and Lemos, 2015, 186). In other words, according to Klaus Radunski, a member of the UNFCCC Adaptation Committee, adaptation "is all the extra effort that we will need to put in, thanks to climate change, to achieve the recently announced UN Sustainable Development Goals" (cited in Helleman, 2015).

Therefore, a different awareness is emerging about the link between adaptation and development but this is far from being new. It is worth remembering that the third assessment report (TAR) of the IPCC had already "assessed preliminary work on the linkage between adaptation, mitigation, and development paths" (IPCC, 2001, 3) and clearly showed that two legs (mitigation and adaptation) are needed to tackle climate change (see Fig. 1). In the Summary for Policy Makers, the TAR stated: "The climate 
change issue is part of the larger challenge of sustainable development. As a result, climate policies can be more effective when consistently embedded within broader strategies designed to make national and regional development paths more sustainable. This occurs because the impact of climate variability and change, climate policy responses, and associated socio-economic development will affect the ability of countries to achieve sustainable development goals. Conversely, the pursuit of those goals will in turn affect the opportunities for, and success of, climate policies. In particular, the socio-economic and technological characteristics of different development paths will strongly affect emissions, the rate and magnitude of climate change, climate change impacts, the capability to adapt, and the capacity to mitigate" (IPCC, 2001, SPM, 4). This conviction of the IPCC has not changed over time and has been reiterated in subsequent reports. In the Summary for Policymakers (SPM) of AR5, for example, it is written, "Many adaptation and mitigation options can help address climate change, but no single option is sufficient by itself. Effective implementation depends on policies and cooperation at all scales and can be enhanced through integrated responses that link adaptation and mitigation with other societal objectives. Adaptation and mitigation responses are underpinned by common enabling factors. These include effective institutions and governance, innovation and investments in environmentally sound technologies and infrastructure, sustainable livelihoods and behavioral and lifestyle choices" (IPCC, 2014, SYR-SPM, 26).

What is new is that an increasing number of declarations shows that the separate approach towards mitigation, adaptation and development seems to be overtaken, both at the political and scholarly levels. During the "One Planet Summit" held on 12 December 2017, two years after the Paris Conference, the French President, Emmanuel Macron, posed the problem in these terms: without "a shock in our own modes of production and of development" it will be impossible to contain the increase in temperatures below the threshold of $2^{\circ} \mathrm{C}$ and a fortiori $1.5^{\circ} \mathrm{C}$ (cited in Bonnefous, et al., 2017). Gupta and Arts claim that the Paris Agreement and the Sustainable Development Goals of the Agenda 2030 "partly complement and partly merge with each other" and "this basically calls on all states to redefine their development paths. This is no longer a question of sharing the carbon cake - which is a zero sum game - but a question of identifying and developing along country specific decarbonized development paths" (Gupta and Arts, 2018, 25). A "safe and just" development space would be possible according to O'Neill and his colleagues: "Strategies to improve physical and social provisioning systems, with a focus on sufficiency and equity, have the potential to move nations towards sustainability, but the challenge remains substantial" (O’Neill et al., 2018). 


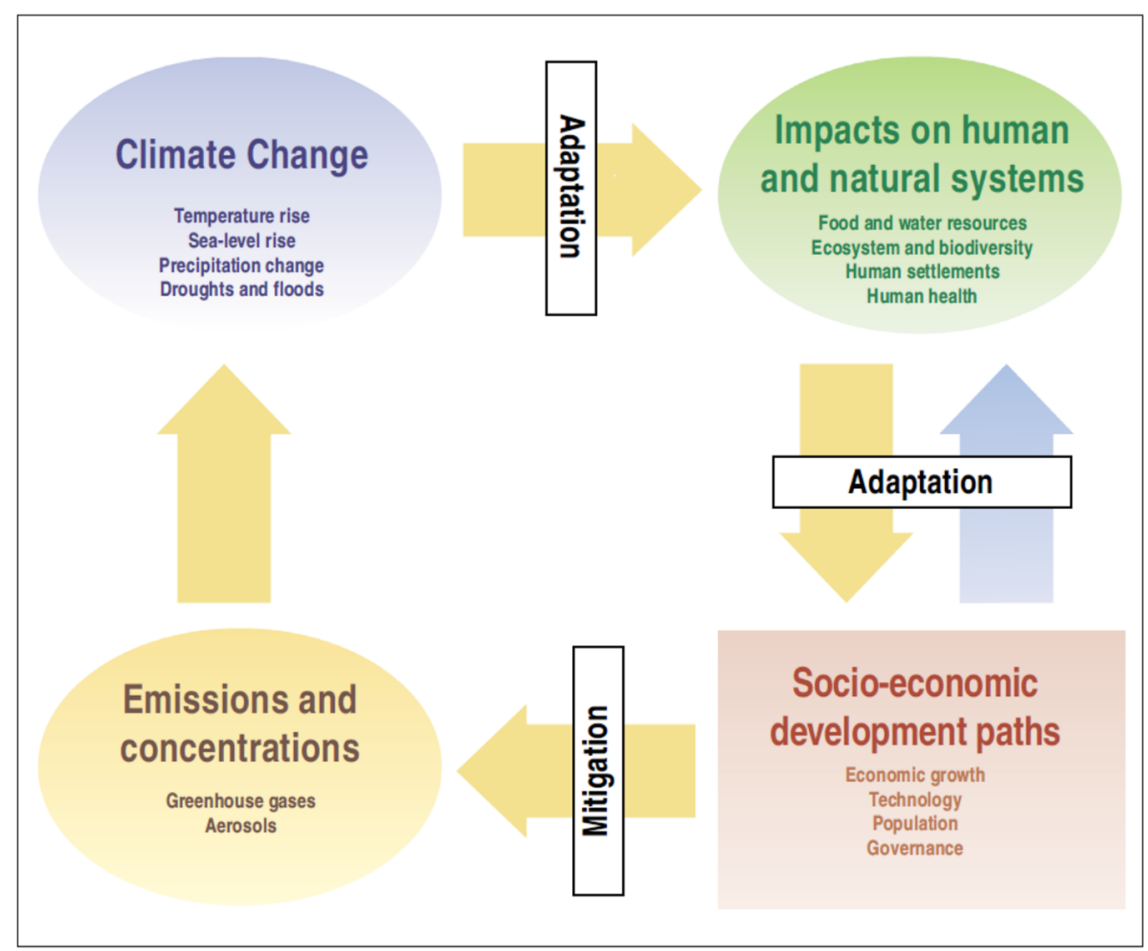

Source: IPCC, Climate Change 2001, Synthesis Report, SPM, 3

On closer inspection, this is a return to the spirit of the Bruntland Report (UN, 1987) and to the origins of the Framework Convention, according to which it is necessary to fight against climate change but, at the same time, to promote economic development: "The Parties have a right to, and should, promote sustainable development. Policies and measures to protect the climate system against human-induced change should be appropriate for the specific conditions of each Party and should be integrated with national development programmes, taking into account that economic development is essential for adopting measures to address climate change" (UNFCCC, Art. 3.4). Precisely for this reason, a fundamental aspect of the Paris Agreement is that: "As part of a global effort, developed country Parties should continue to take the lead in mobilizing climate finance from a wide variety of sources, instruments and channels, noting the significant role of public funds, through a variety of actions, including supporting country-driven strategies, and taking into account the needs and priorities of developing country Parties. Such mobilization of climate finance should represent a progression beyond previous efforts" (Art. 9, par. 3). 
To say that sustainable development requires mitigation, adaptation and a new look to development aid is quite a trivial matter. What is not trivial and is not univocally determined is how to implement this principle.

\section{References}

Agrawal A., Lemos M.C. (2015). Adaptive development. Nature Climate Change, 5(3): 185187. DOI: $10.1038 /$ nclimate2501.

Bonnefous B. et al. (2017). Emmanuel Macron: «Il faut un choc dans nos modes de production». Le Monde, December 12 -- http://www.lemonde.fr/planete/article/2017/12/12/ emmanuel-macron-il-faut-un-choc-dans-nos-modes-de-production_5228401_3244.html.

Burton I. (1994). Deconstructing adaptation and reconstructing. Delta, 5(1): 14-15.

Cox P.M., Huntingford C., Williamson M.S. (2018). Emergent constraint on equilibrium climate sensitivity from global temperature variability. Nature, 18 January 2018. DOI: 10.1038 /nature25450.

CTI (Carbon Tracker Initiative) (2018). Carbon budgets explained -- https://www.carbon tracker.org/wp-content/uploads/2018/02/Carbon-Budgets_Eplained_02022018.pdf.

Damian M. (2016). A new political economy of climate change. Economics and policy of energy and the environment, 57(2/2015): 5-14. DOI: 10.3280/efe2015-002001.

Damian M. (2014). La politique climatique change enfin de paradigme. Economie Appliquée, tome LXVII(1): 37-72.

Damian M. (2007). Il faut réévaluer la place de l'adaptation dans la politique climatique. $\mathrm{Na}$ tures Sciences Sociétés, 15: 407-410. DOI: 10.1051/nss:2008010.

DeLeo R.A. (2017). Anticipatory policymaking in global venues: Policy change, adaptation, and the UNFCCC. Futures, 92: 39-47. DOI: 10.1016/j.futures.2016.09.001.

De Paoli L. (2015). The fight against climate change: Some proposal for action for Italy in Europe. Economics and policy of energy and the environment, 1: 9-27. DOI: 10.3280/efe2015-001002.

Dovie D.B.K., Lwasa S. (2017). Correlating negotiation hotspot issues, Paris climate agreement and the international climate policy regime. Environmental Science \& Policy, 77: 18. DOI: 10.1016/j.envsci.2017.07.010.

EEA (2018). Atmospheric greenhouse gas concentrations -- https://www.eea.europa.eu/ downloads/2544a644eb9a4648b40c998b9bd3148b/1517395177/assessment.pdf.

ESRL-NOAA (2018). Trends in Atmospheric Carbon Dioxide -- https://www.esrl.noaa.gov/ gmd/ccgg/trends/gl_gr.html.

Faran T.S., Olsson L. (2018). Geoengineering: neither economical, nor ethical - a risk - reward nexus analysis of carbon dioxide removal. International Environmental Agreements: Politic, Law and Economics, 18(1): 63-77. DOI: 10.1007/s10784-017-9383-8.

Gao Y., Gao X., Zhang X. (2017). The $2{ }^{\circ} \mathrm{C}$ Global Temperature Target and the Evolution of the Long-Term Goal of Addressing Climate Change - From the United Nations Framework Convention on Climate Change to the Paris Agreement. Engineering, 3: 272-278. DOI: 10.1016/J.ENG.2017.01.022.

Gupta J., Arts K. (2018). Achieving the $1.5^{\circ} \mathrm{C}$ objective: just implementation through a right to (sustainable) development approach. International Environmental Agreements: Politics, Law and Economics, 18(1): 11-28. DOI: 10.1007/s10784-017-9376-7.

Hall N. (2017). What is adaptation to climate change? Epistemic ambiguity in the climate finance system. International Environmental Agreements: Politics, Law and Economics, 17(1): 37-53. DOI: 10.1007/s10784-016-9345-6. 
Hall N., Persson A. (2017). Global climate adaptation governance: Why is it not legally binding?, European Journal of International Relations. DOI: 10.1177/1354066117725157.

Hanemann, M., 2008. Observations on the Economics of Adaptation: Uncertainty and Timing, Presentation, Paris, OECD Workshop on the Economics of Adaptation, April 7-8 -http://www.oecd.org/env/cc/40897430.pdf.

Hansen J. et al. (2013). Assessing "Dangerous Climate Change": Required Reduction of Carbon Emissions to Protect Young People, Future Generations and Nature, PLoS ONE 8(12): e81648. DOI: 10.1371/journal.pone.0081648.

Heede R., Oreskes N. (2016). Potential emissions of CO2 and methane from proved reserves of fossil fuels: An alternative analysis. Global Environmental Change, 36: 12-20. DOI: 10.1016/j.gloenvcha.2015.10.005.

Helleman J. (2015). Everyone knows climate adaptation is crucial, but beyond that it's pretty hazy. The Conversation Global, December 5 -- https://theconversation.com/ everyone-knows-climate-adaptation-is-crucial-but-beyond-that-its-pretty-hazy-51919.

Honegger M., Rainer D. (2018). The political economy of negative emissions technologies: consequences for international policy design. Climate Policy, 18(3): 306-321. DOI: 10.1080/14693062.2017.1413322.

Hood M. (2018). 1.5 C climate goal 'very unlikely' but doable: draft UN report. Phys.org, January 13 -- https://phys.org/news/2018-01-climate-goal-doable.html.

IEA-OECD (2008). World Energy Outlook, WEO ed 2008 and ed. 2017, OECD/IEA, www.iea.org.

IEA (2017). $\mathrm{CO}_{2}$ emissions from fuel combustion: Highlights, $2017 \mathrm{ed}$.

IPCC (2001). Climate Change 2001: Synthesis Report, Summary for Policymakers -https://www.ipcc.ch/ipccreports/tar/vol4/english/pdf/spm.pdf.

IPCC (2005). Carbon Dioxide Capture and Storage -- https://www.ipcc.ch/report/srccs/.

IPCC (2007). Climate Change 2007: Synthesis Report -- www.ipcc.ch/publications_and_ data/ar4/syr/en/spms5.html.

IPCC (2013). Climate Change 2013: The Physical Science Basis, Geneva -https://www.ipcc.ch/pdf/assessment-report/ar5/wg1/WG1AR5_Chapter08_FINAL.pdf.

IPCC (2014). Climate Change 2014. Synthesis Report. Summary for Policymakers. Geneva -- https://www.ipcc.ch/pdf/assessment-report/ar5/syr/AR5_SYR_FINAL_SPM.pdf.

IPCC (2014). Climate Change 2014: Mitigation of Climate Change, Summary for Policymakers -- http://www.ipcc.ch/pdf/assessment-report/ar5/wg3/ipcc_wg3_ar5_summaryfor-policymakers.pdf.

Jaeger C.C., Jaeger J. (2010). Three Views of Two Degrees. ECF Working Paper 2/2010.

Lesnikowski A. et al. (2017). What does the Paris Agreement mean for adaptation? Climate Policy, 17(7): 825-831.

McGlade C., Ekins P. (2014). Un-burnable oil: An examination of oil resource utilisation in a decarbonised energy system. Energy Policy, 64: 102-112. DOI: 10.1016/j.enpol.2013.09.042.

Mekouar M.A. (2017). L'Afrique à l'épreuve de l'Accord de Paris. Revue Juridique de l'Environnement, 42(HS03): 59-71.

Morocco (2015). Intended Nationally Determined Contribution. UNFCCC, June 5. --http://www4. unfccc.int/submissions/INDC/Published\%20Documents/Morocco/1/Morocco\%20INDC\%20 submitted $\% 20$ to $\% 20$ UNFCCC $\% 20-\% 205 \% 20$ june $\% 202015$.pdf.

Nieto J. et al. (2018). Less than $2{ }^{\circ} \mathrm{C}$ ? An Economic-Environmental Evaluation of the Paris Agreement. Ecological Economics, 146: 69-84.

OECD-ITF (2018). Transport $\mathrm{CO}_{2}$ and the Paris Climate Agreement: Reviewing the Impact of Nationally Determined Contributions, https://www.itf-oecd.org/transport-co2-parisclimate-agreement-ndcs.pdf. 
O'Neill D.V. et al. (2018). A good life for all within planetary boundaries. Nature Sustainability, 1: 88-95 -- https://www.nature.com/articles/s41893-018-0021-4.epdf.

Pielke Jr. R.A. (1998). Rethinking the role of adaptation in climate policy. Global Environmental Change, 8(2): 159-170. DOI: 10.1016/s0959-3780(98)00011-9.

Pielke Jr. et al. (2007). Lifting the taboo on adaptation. Nature, 445(7128): 597-598. DOI: $10.1038 / 445597 \mathrm{a}$.

Reuters (2018). Warming set to breach Paris accord's toughest limit by mid century: draft. January 11 -- https://www.reuters.com/article/us-climatechange-draft/warming-set-to-breach -paris-accords-toughest-limit-by-mid-century-draft-idUSKBN1F02RH.

Rojelj J. et al. (2018). Scenarios towards limiting global mean temperature increase below 1.5 ${ }^{\circ} \mathrm{C}$. Nature Climate Change, 8: 325-332. DOI: 10.1038/s41558-018-0091-3.

Rousset N. (2012). Economie du changement climatique: Des politiques d'atténuation aux politiques d'adaptation. Thèse de doctorat en sciences économiques, Laboratoire Economie du développement durable et de l'énergie (EDDEN, CNRS), Université Grenoble Alpes, 20 décembre.

Schelling T.C. (1983). Climatic Change: Implications for Welfare and Policy, in National Research Council. Changing Climate: Report of the Carbon Dioxide Assessment Committee, Washington, DC, National Academy Press, 449-482.

Schelling T.C. (2007). Climate Change: The Uncertainties, the Certainties, and What They Imply About Action. Economists'Voice -- www.bepress.com/ev.

Scott Hosking J., MacLeod D., Phillips T., Holmes C.R., Watson P., Shuckburgh E.F., Mitchell D. (2018). Changes in European wind energy generation potential within a $1.5{ }^{\circ} \mathrm{C}$ warmer world. Environ. Res. Lett. 13 (2018) 054032. DOI: 10.1088/1748-9326/aabf78.

Stern N. (2009). A blueprint for a safer planet: How to manage climate change and create a new era of progress and prosperity. Bodley Head, London.

Stern N. (2006). Stern Review: The Economics of Climate Change. HM Treasury, London.

United Nations (1987). Report of the World Commission on Environment and Development: Our Common Future, (also known as "Bruntland Report") -- http://www.un-documents. net/our-common-future.pdf.

United Nations (1992). United Nations Framework Convention on Climate Change -https://unfccc.int/resource/docs/convkp/conveng.pdf.

United Nations (2009). Copenhagen Accord, FCCC/CP/2009/11/Add.1 -- https://unfccc.int/ resource/docs/2009/cop15/eng/11a01.pdf.

United Nations (2015). Adoption of the Paris Agreement. Paris, December 12 -- https:// unfccc.int/resource/docs/2015/cop21/eng/109r01.pdf.

Victor D.G., Kennel C.F. (2014). Ditch the $2{ }^{\circ} \mathrm{C}$ warming goal. Nature, 514, 2 October: 3031. DOI: $10.1038 / 514030$ a.

Vidal J. (2018). How Bill Gates aims to clean up the planet. The Guardian.com, February 4 -https://www.theguardian.com/environment/2018/feb/04/carbon-emissions-negative-emissionstechnologies-capture-storage-bill-gates. 